\title{
DUKUNGAN STANDARDISASI PADA BUDIDAYA TIRAM MUTIARA
}

\section{Standardization Support on Pearl Oyster Cultivation}

\author{
Ellia Kristiningrum dan Bendjamin BL \\ Pusat Penelitian dan Pengembangan Standardisasi, Badan Standardisasi Nasional \\ Gedung 1 BPPT Lantai 12 JI MH Thamrin No. 8 Jakarta Pusat, Indonesia \\ e-mail: ellia@bsn.go.id
}

Diterima: 29 Junil 2018, Direvisi: 26 Juli 2018, Disetujui: 1 Agustus 2018

\begin{abstract}
Abstrak
Perkembangan usaha budidaya mutiara telah mengarah pada kegiatan industri yang terintegrasi. Terdapat 4 proses utama dalam budidaya tiram mutiara yaitu proses pembenihan, pendederan dan pembesaran tiram mutiara, serta proses operasi (penyisipan nukleus). Penelitian ini bertujuan untuk memberikan gambaran tahapan budidaya tiram mutiara dan melakukan analisa perlu tidaknya pengembangan SNI untuk tahapan insersi nukleus ke dalam tubuh tiram mutiara. Metode analisa deskriptif berdasarkan data dari 3 pengusaha tiram mutiara yang berada di wilayah Bali, Labuan Bajo dan Manado digunakan untuk mengungkapkan budidaya tiram mutiara serta menganalisa kebutuhan pengembangan standarnya. Penelitian ini menemukan 4 SNI pendukung budidaya tiram mutiara yaitu SNI pendederan tiram mutiara, SNI tiram mutiara induk, SNI tiram mutiara spat dan SNI mutiara. Hasil analisa menunjukkan bahwa pengembangan standar untuk proses operasi atau teknik insersi tidak perlu dilakukan, hal ini dikarenakan faktor kompetensi pelaku insersi dan faktor eksternal (lingkungan) lebih mendominasi terhadap keberhasilan pembentukan mutiara, sehingga kualitas mutiara yang dihasilkan belum tentu seragam meskipun dilakukan dengan teknik insersi yang sama. Penyusunan tatacara dan persyaratan proses insersi tiram mutiara dijadikan dapat pedoman untuk mendukung standardisasi kegiatan budidaya tiram mutiara.
\end{abstract}

Kata kunci: ekspor, mutiara, SNI, teknik insersi.

\section{Abstract}

The development of pearl farming has led to integrated industrial activities. There are four main processes in the cultivation of pearl oysters is the process of seeding, nursery and grown-pearl oyster, as well as the process of operation (insertion nucleus). This study aims to provide an overview of the stages of pearl farming and analyzing whether or not the development of SNI for insertion stage of the nucleus into the body of the pearl oyster. Descriptive analysis methods based on data from 3 pearl oyster entrepreneurs located in Bali, Labuan Bajo and Manado are used to reveal the cultivation of pearl oysters as well as to analyze their standard development needs. This study found 4 SNI support pearl oyster cultivation namely nursery pearl oyster standard, mother of pearl oyster standard, spat pearl oyster standard and pearls standard. The result of the analysis shows that the development of standard for operation process or insertion technique is not necessary, this is because competence factor of insertion and external factor (environment) dominates the success of pearl formation, so the quality of pearls produced is not necessarily uniform although done by insertion technique same. Preparation of procedure and requirement of pearl oyster insertion process can be guidance to support standardization of pearl shell cultivation activity.

Kata kunci: export, pearl, SNI, insertion technique.

\section{PENDAHULUAN}

Mutiara merupakan produk hasil perikanan berupa butiran permata yang dihasilkan oleh tiram laut dan air tawar, salah satunya tiram jenis Pinctada maxima. Produk mutiara yang dihasilkan Indonesia dan Australia menguasai 25\% produksi mutiara dunia (Sudewi dkk, 2010). Perkembangan usaha budidaya mutiara Indonesia telah mengarah pada kegiatan industri terintegrasi (Winanto, 2009) menyumbangkan nilai ekspor (HS 7101) pada tahun 2016 mencapai nilai 45.293 ribu US\$. Produk ini diekspor ke 9 negara, yang terbesar yaitu ke Negara Hongkong, Australia, Jepang dan China. Mutiara yang diekspor ini terdiri dari $68 \%$ mutiara dari alam, 32\% mutiara hasil budidaya (Trademap, 2017).

Gaya hidup masyarakat terhadap konsumsi produk perikanan, termasuk perhiasan, menjadikan mutiara sebagai komoditas budidaya perikanan yang strategis disamping budidaya 
rumput laut dan kerapu (Sukadi, 2002). Budidaya ini merupakan salah satu bisnis yang diminati dengan jumlah produsen yang tercatat sebagai anggota ASBUMI (Asosiasi Budidaya Mutiara Indonesia) sebanyak 32 perusahaan dengan bentuk investasi PMDN, PMA dan swasta nasional. Teknik budidaya tiram mutiara, khususnya untuk hatchery dan operasi penyuntikan, awalnya dikembangkan oleh tenaga asing (Jepang), namun dengan perkembangan teknologi dan ilmu pengetahuan di bidang kelautan, mengakibatkan terjadinya alih teknologi dari tenaga asing ke tenaga kerja Indonesia untuk operasi penyuntikan dan hatchery (Hamzah, 2013).

$\mathrm{Di}$ pasar internasional mutiara yang dihasilkan oleh Pinctada maxima dikenal dengan sebutan Mutiara Laut Selatan (MLS) atau south sea pearl, dan $26 \%$ berasal dari Indonesia. Di Nusa Tenggara Barat, budidaya ini terdapat di perairan Laut Sumbawa yang memiliki arus tenang. Dilihat dari ukurannya, tiram jenis ini berukuran lebih besar dari pada jenis lainnya, sehingga berpeluang menghasilkan mutiara yang besar pula. (BI, 2004)

Pembentukan mutiara secara alami merupakan respon tiram dalam menolak rasa sakit karena adanya benda asing yang masuk ke dalam tubuhnya, misalnya pasir atau nukleus. Rasa sakit itu memerintahkan mantel yang merupakan jaringan hidup untuk membentuk lapisan yang mengelilingi nukleus dan berlangsung secara alamiah.

Terdapat 4 proses utama dalam budidaya mutiara yaitu proses pembenihan, pendederan dan pembesaran tiram, serta proses operasi (penyisipan nukleus). Proses penyisipan nukleus atau yang lebih dikenal dengan istilah insersi inti ke dalam tubuh tiram menjadi salah satu proses paling penting dalam budidaya. Insersi ini dilakukan pada musim kemarau untuk menghindari kemungkinan inti atau nukleus keluar dari tubuhnya tiram, karena pada musim penghujan, inti bisa keluar bersama sel-sel telur saat musim-musim reproduksi tiram berlangsung.

Pengembangan standar sangat penting untuk menjamin kualitas produk. Keberadaannya tidak hanya ditujukan untuk melindungi konsumen tetapi juga untuk menciptakan perdagangan yang adil dan meningkatkan daya saing bangsa. Menurut (Sumarto dkk, 2014), dalam konteks perdagangan internasional standar memiliki peranan yang lebih luas yaitu, 1) melindungi kepentingan masyarakat internasional terutama terkait dengan aspek perlindungan konsumen, 2) memfasilitasi tercapainya perdagangan internasional yang baik, 3) dan meningkatkan kesejahteraan masyarakat.

148
Sampai dengan tahun 2017, Badan Standardisasi Nasional telah menetapkan SNI yang dimaksudkan untuk mendukung proses budidaya tiram mutiara yang selama ini dilakukan, namun untuk teknik penyisipan nukleus (insersi inti) belum disusun SNI nya. Sehubungan dengan hal tersebut, untuk melengkapi standar dalam mendukung budidaya tiram mutiara, maka perlu dilakukan analisa terkait perlu tidaknya pengembangan standardisasi teknik insersi mutiara.

Tabel 1 Standar Nasional Indonesia yang mendukung budidaya tiram mutiara.

\begin{tabular}{lcl}
\hline NO & NOMOR SNI & \multicolumn{1}{c}{ JUDUL SNI } \\
\hline 1 & SNI 7874-2013 & $\begin{array}{l}\text { Pendederan spat tiram } \\
\text { mutiara }\end{array}$ \\
\hline 2 & SNI 8146.1-2015 & Tiram mutiara induk \\
\hline 3 & SNI 8146.2-2015 & Tiram mutiara spat \\
\hline 4 & SNI 4989-2016 & Mutiara laut selatan \\
\hline
\end{tabular}

Sumber: BSN, 2017

Penelitian ini bertujuan untuk memberikan gambaran tahapan budidaya tiram mutiara dan melakukan analisa perlu tidaknya pengembangan SNI untuk tahapan insersi nukleus ke dalam tubuh tiram mutiara.

\section{TINJAUAN PUSTAKA}

\section{$2.1 \quad$ Tiram Mutiara}

Data Kementerian Kelautan dan Perikanan (KKP, 2016) menunjukkan volume komoditas mutiara menunjukkan angka 29 Ton dengan nilai sebesar 31.239 ribu US\$. Indonesia memiliki areal budidaya dan potensi lahan untuk pengembangan budidaya laut, khususnya tiram mutiara yaitu sebesar 62.040 ha, namun pemanfaatannya hanya sebesar $1 \%$ Saat ini, dari total produksi mutiara yang ada di pasar internasional sekitar $26 \%$ berasal dari Indonesia.

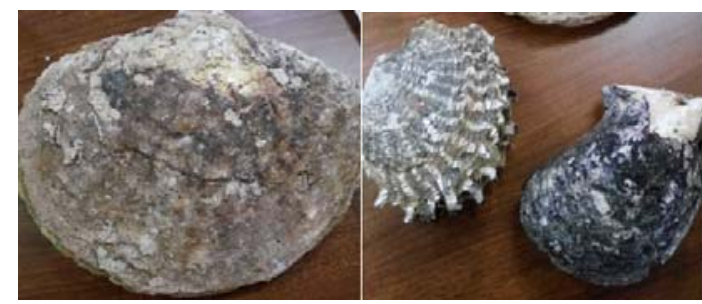

Gambar 1 Tiram mutiara.

Pengelolaan dan pemanfaatan potensi sumber daya hayati laut yang berlimpah belum dilakukan secara optimal (Fathurrahman \& 
Aunurohim, 2014). Tiram mutiara (Familia pteriidae) adalah penghasil mutiara yang paling umum dibudidayakan untuk mutiaranya. Sutarman (1993) menyebutkan bahwa secara rinci tiram mutiara dapat diklasifikasikan sebagai berikut:

- Kingdom : Invertebrate

- Phyllum : Molusca

- Klass : : Pellecypoda atau Lamellibranchiata

- Orda : Anysomyaria

- Famili : Pteridae

- Spesies : Pinctada sp. dan Pteria sp.

- Nama dagang : Pearl oyster

Jenis-jenis tiram mutiara yang ada di Indonesia yaitu:

- Pinctada maxima - tiram mutiara bibir emas/perak

- $\quad$ Pinctada margaritifera - tiram mutiara bibir hitam

- $\quad$ Pinctada fucata - tiram mutiara Akoya

- $\quad$ Pteria penguin - tiram mutiara bersayap

Tiram mutiara memiliki bentuk luaran seperti batu karang dan terlihat seperti tidak ada kehidupan. Tiram tersebut memiliki cangkang yang tidak simetris dan sangat keras yang dibagian punggungnya terdapat engsel yang berfungsi melindungi bagian lunak yang ada di dalamnya. Bagian lunak ini merupakan organ yang dapat mengatur segala aktivitas kehidupan dari tiram itu sendiri. Di sisi sebelah dalam dari cangkang tersebut terdapat lapisan induk mutiara serta nacre yang bertugas membentuk lapisan mutiara dengan penampilan mengkilap (Kotta, 2018).

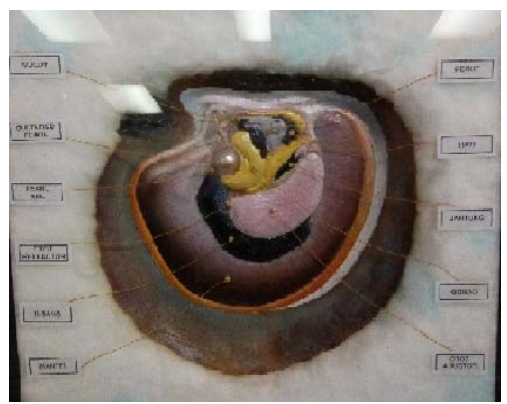

Gambar 2 Anatomi dan Formasi Silver South Sea Pearl

Spesies tiram yang banyak dibudidayakan adalah Pinctada fucata, $P$. maxima, P. margatifera dan Pteria penguin. Spesies-spesies ini banyak tersebar di kawasan Indo-Pasifik, mulai dari perairan Samudera Hindia sampai di Samudera Pasifik termasuk perairan Indonesia. (Makhas dkk, 2014). Pictada maxima yang banyak dibudidayakan di Indonesia, merupakan moluska laut dengan tubuh dilindungi atau ditutupi sepasang cangkang, termasuk kelas Bivalvia dan family Pteriidae. Di dunia internasional, mutiara yang diproduksi disebut dengan nama south sea pearl. Tiram ini merupakan jenis tiram yang memiliki ukuran paling besar, dimana tempat hidupnya mulai dari perairan dangkal sampai dasar perairan berpasir, atau pasir berkarang yang ditumbuhi tanaman lamun sampai laut dalam berkarang. Tiram ini biasanya hidup menempel pada karang pada kedalaman 10 - $75 \mathrm{~m}$ (Gervis \& Sims, 1992) dan kedalaman $50-100 \mathrm{~cm}$ (Winanto dkk, 1992) dengan substrat bersedimen di daerah yang berdekatan dengan landas kontinen dan paparan pulau.

\subsection{Budidaya Tiram Mutiara}

Budidaya mutiara pertama kali dipraktekkan oleh ilmuwan Jepang yang bernama Mikimoto pada tahun 1943 melalui perjalanan uji coba penelitian yang panjang untuk menghasilkan butiran mutiara yang akhirnya ditemukan Pearl Cultured nya. Hal yang menjadi dasar pemikirannya adalah ketersediaan stok butir mutiara laut asli yang sudah mulai sulit ditemui dan hampir punah (Hakim, 2015). Seiring dengan perkembangan waktu dan banyaknya permintaan akan mutiara, pembudidaya tiram mutiara ( $P$. maxima) pada beberapa daerah di Indonesia harus memesan benih dari luar daerah atau dari perusahaan lain (Hamzah, 2013).

Budidaya tiram mutiara dimulai dengan proses pembenihan, pendederan, pembesaran tiram mutiara, operasi dan pemeliharaan. Pada proses pembenihan, pendederan dan pembesaran tiram mutiara, tiram ditangkap dari alam dan dilakukan pemijahan (dikawinkan antara induk betina dan jantan). Penetasan telur dipelihara di bak kontrol laboratorium sebelum dipindahkan ke perairan laut dengan metode pemeliharaan Longline. Proses pembesaran dengan target ukuran $15-20 \mathrm{~cm}$ dengan proses pemeliharaan selama +- 15 bulan dilakukan untuk memastikan tiram siap dioperasi. Pemeliharaan tiram mutiara harus mendapatkan perhatian khusus, salah satu penyebab rendahnya pertumbuhan dan kelulushidupan pada perkembangan awal larva sampai spat mutiara adalah pemberian makanan alami yang kurang tepat (Taufiq dkk, 2010). 
Proses operasi (penyisipan nukleus) merupakan proses penyisipan inti ke dalam tubuh tiram yang merupakan proses fundamental dari serangkaian kegiatan budidaya tiram mutiara. Dalam proses ini diperlukan keahlian, keterampilan, dan pengalaman khusus. Pemasukan nukleus ke dalam tubuh tiram mengakibatkan ekpresi kesakitan yang mengeluarkan cairan dimana jika terakumulasi dalam waktu yang lama akan membentuk sebuah lapisan dan suatu "benda" yang disebut mutiara.
Proses pemeliharaan dilakukan secara rutin dengan monitoring dan pemeriksaan sinar $\mathrm{X}$, untuk mengetahui keberhasilan proses operasi nukleus, biasanya dari total tiram yang disuntik tidak semuanya berhasil, nukleus yang telah disuntikan pada proses operasi dimuntahkan oleh tiram dikarenakan beberapa faktor diantaranya kondisi tiram yang sakit atau kondisi perairan laut yang sudah mencapai batas kapasitas (Hakim, 2015).

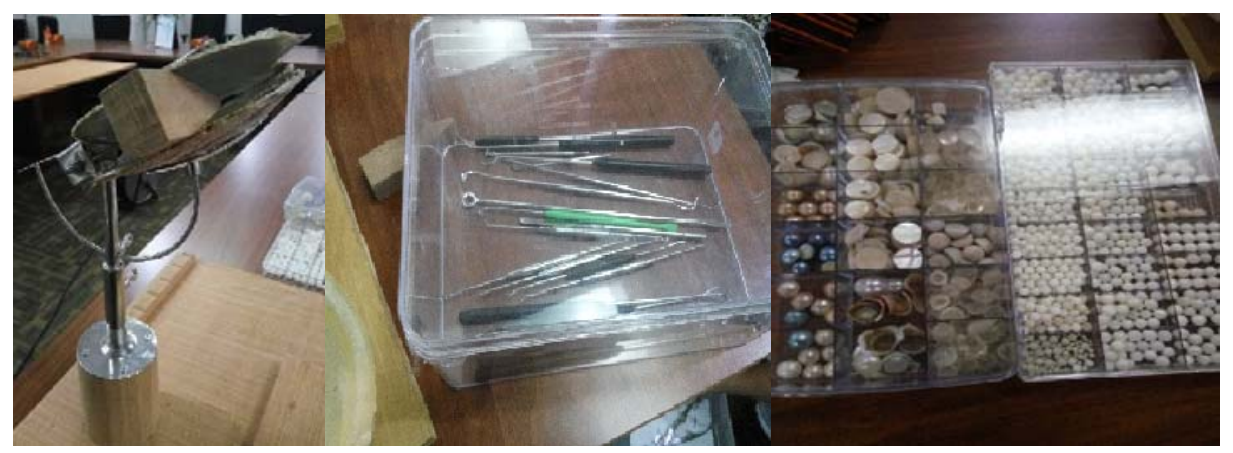

Gambar 3 Opener, peralatan operasi, inti untuk proses operasi tiram mutiara

\section{METODE PENELITIAN}

Komponen-komponen penting dalam budidaya tiram mutiara mencakup pembenihan, pendederan, pembesaran, pengoperasian (insersi). Keberadaan SNI yang mendukung proses tersebut dijadikan input dalam penelitian ini dimaksudkan untuk membantu para pelaku usaha dalam melakukan budidaya tiram mutiara, meskipun terdapat faktor-faktor lainnya yang mempengaruhi. Gap ketersediaan SNI yang ditemukan adalah terdapat salah satu proses yang dalam teori budidaya tiram mutiara merupakan proses yang paling menentukan keberhasilan budidaya, yaitu insersi (operasi) belum tersusun SNI nya.

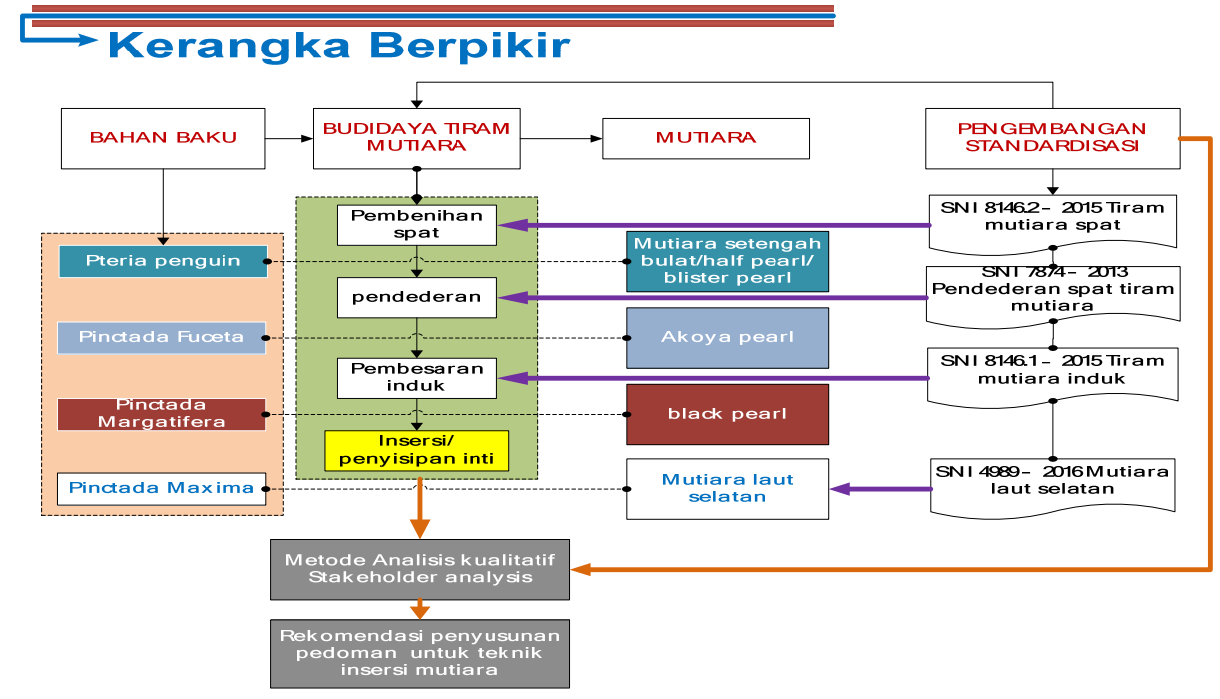

Gambar 5 Kerangka berpikir penelitian. 
Analisis kualitatif dengan menggunakan informasi yang disusun dari para pelaku usaha dijadikan metode untuk melakukan analisa perlu tidaknya pengembangan SNI untuk proses insersi (operasi).

Dalam proses insersi atau operasi tersebut, faktor internal yang mempengaruhi adalah penanganan pra insersi, yaitu proses seleksi dan yokusei (pemuasaan). Penanganan pasca insersi yang juga sangat mempengaruhi keberhasilan operasi adalah penempatan, tento, pemeriksaan retensi/ronsen, dan pembersihan. Faktor eksternal yang juga mempengaruhi keberhasilan terknik insersi adalah pencemaran, kesuburan, climate change/global warming.

Penelitian ini menggunakan metode analisa deskriptif terhadap kasus pada 3 (tiga) pelaku usaha budidaya mutiara yang berada di wilayah Bali, Labuan Bajo dan Manado. Data yang dikumpulkan adalah tata cara budidaya tiram mutiara yang dilakukan oleh responden, serta kebutuhan pelaku usaha untuk pengembangan SNI pada setiap tahapan budidaya tiram mutiara.

\section{HASIL DAN PEMBAHASAN}

\subsection{Proses Budidaya Tiram Mutiara}

Terdapat beberapa metode yang digunakan dalam budidaya tiram mutiara dilakukan, antara lain: rakit apung (floating raft method), metode dasar (bottton method), dan metode tali rentang (long line method), yang masing-masing dilengkapi dengan keranjang pemeliharaan (pocket) (Taufik, et. al, 2007). Hasil penelitian menunjukkan metode yang digunakan pada pembudidaya tiram mutiara di wilayah Bali dan Labuan Bajo adalah metode tali rentang. Skema budidaya tiram mutiara yang selama ini dikembangkan di Indonesia dapat digambarkan dalam Gambar 6 berikut ini:

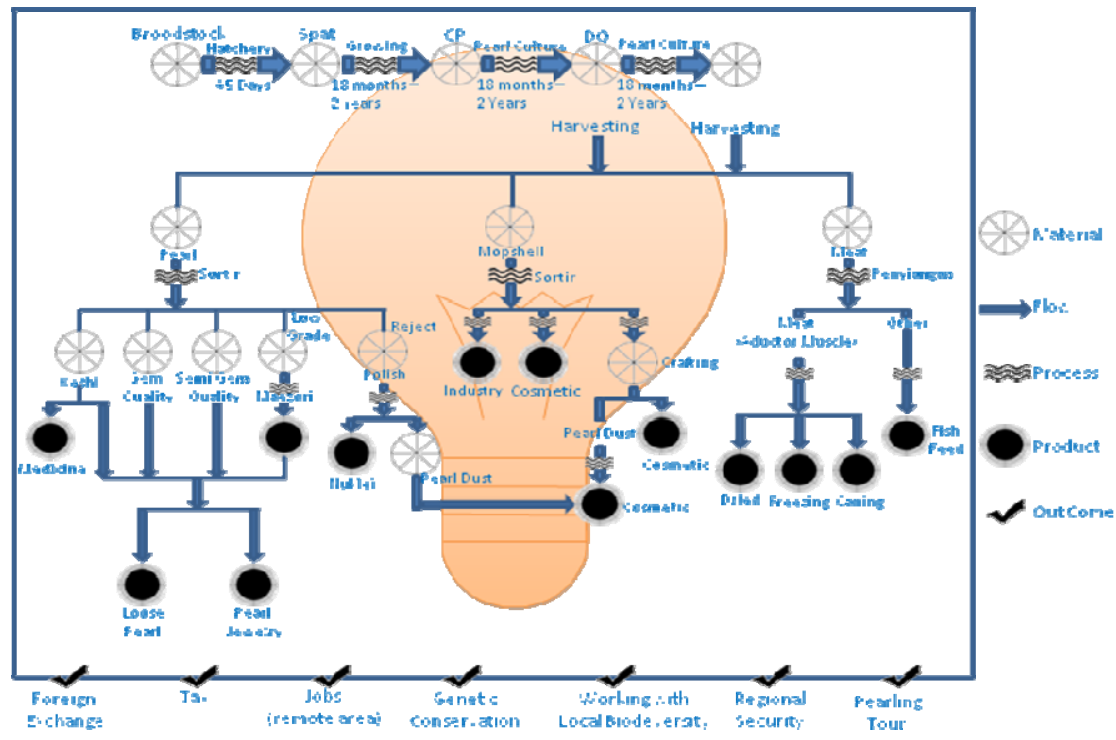

Gambar 6 Skema Budidaya Mutiara Laut Selatan.

Sumber: Mulyanto (2017).

\subsubsection{Broodstock (Indukan)}

Hasil penelitian menunjukkan bahwa ketiga responden menggunakan induk tiram mutiara hasil pembenihan. Seleksi induk tiram dilakukan berdasarkan pedoman dari perusahaan terkait dengan ukuran cangkang, keutuhan cangkang, dan warna cangkang. Ketiga responden tidak mengetahui keberadaan SNI 8146.1:2015 yang telah mengatur kriteria persyaratan untuk induk tiram mutiara. Persyaratan yang diatur adalah persyaratan kualitatif dan kuantitatif. Dalam persyaratan kualitatif, induk tiram mutiara minimal harus mencakup: a. Asal induk: dari alam dan atau hasil pembesaran spat yang berasal dari keturunan pertama perkawinan antar induk alam yang telah diseleksi

b. Warna cangkang: bagian luar kuning kecoklatan bersih dari spot warna hitam dan bagian dalam berwarna putih keperakan atau keemasan yang berkilau

c. Bentuk tubuh: memiliki sepasang cangkang yang berntuknya pipih dan cembung dengan diameter dari dorsam sampai ventral dan dari anterior sampai posterior hamper sama, sehingga hampir bundar, organ tubuh bagian dalam sangat lunak 
d. Kesehatan: cangkang bagian luar tidak cacat dan tidak ditempeli oleh organisme penempel (fouling organism), organ tubuh bagian dalam khususnya gonand tidak tampak kelainan bentuk, sehat dan bebas pathogen (bakteri, virus) dan parasit

e. Gerakan: respon cepat saat ada gangguan dari luar, dengan cara menutup rapat kedua cangkangnya

f. Mantel memenuhi semua ruang cangkang bagian dalam

g. Kematangan gonad: induk jantan ditandai dengan gonad penuh dengan warna putih susu dan induk betina gonad penuh dengan warna kuning kemerahan

h. Tingkat kematangan gonad induk III dan IV

Untuk persyaratan kuantitatif, hasil penelitian menunjukkan bahwa ketiga responden menyampaikan ukuran cangkang tiram mutiara yang siap untuk di insersi antara $11-13 \mathrm{~cm}$ dengan umur pemeliharaan kurang lebih 1,5 tahun. Di dalam SNI diatur umur minimal 3 tahun dimulai dari telor menetas samapi indusk siap utnuk dipijahkan.

Tabel 2 Kriteria kuantitaif induk tiram mutiara.

\begin{tabular}{clcc}
\hline No & Kriteria kuantitatif & Satuan & Persyaratan \\
\hline 1 & Panjang engsel & $\mathrm{cm}$ & Minimal 12 \\
2 & Ketebalan cangkang & $\mathrm{cm}$ & $1,5-2,0$ \\
3 & Bobot & $\mathrm{g}$ & Minimal 500 \\
4 & Umur & tahun & Minimal 3 \\
\hline
\end{tabular}

Sumber: BSN, 2015

SNI ini dirumuskan untuk menjamin mendapatkan induk yang sehat dan berkualitas, karena mempengaruhi proses pembenihan yang nantinya akan mempengaruhi mutiara yang dihasilkan.

\subsubsection{Hatchery (Pembenihan)}

Keberhasilan pengembangan teknologi hatchery untuk produksi tiram mutiara telah dikembangkan sekitar tahun 1980an. Responden menyampaikan bahwa faktor utama yang harus diperhatikan adalah pemilihan tempat. Tempat yang digunakan untuk pembenihan harus terbebas dari polusi dengan mutu air laut yang baik yang ditunjukkan dengan tidak adanya partikel tersuspensi dan lumpur, koral, pasir. Lokasi yang digunakan oleh semua responden terbebas dari limbah industri, rumah tangga, serta muara sungai.

Faktor selanjutnya adalah bangunan yang digunakan harus dirancang untuk mendapatkan cahaya dan udara yang maksimal, diperlukan ventilasi udara dan kipas angin dalam jumlah yang cukup. Responden juga menyampaikan penggunaan $A C$ dengan suhu tinggi terbukti berhasil membantu dalam pembesaran larva. Pengaruh suhu sangat menentukan keberhasilan pembenihan induk. Hal ini diperkuat dari penelitian yang dilakukan oleh Hamzah (2009) yang menyebutkan bahwa terjadi kematian massal pada anakan tiram mutiara bersama dengan naiknya suhu harian dari level $29^{\circ} \mathrm{C}$ menjadi $31^{\circ} \mathrm{C}$.
Faktor lain yang juga harus diperhatikan adalah pengelolaan air, aerasi, produksi makanan larva, isolasi, stok bahan baku, produksi alga, kondisi pembenihan, pengelolaan benih, system pemeliharaan larva, penyakit yang menjangkiti larva, produksi spat, dll. Dalam proses hatchery, dibutuhkan waktu 45 hari yang dimulai dari proses peneluran dilanjutkan dengan pembuahan dan akhirnya menjadi benih (spat). Proses ini merupakan masa kritis dalam pengembangan larva, dimana pengaruh perubahan parameter lingkungan khususnya suhu sangat berpengaruh terhadap pertumbuhan dan kelangsungan hidup larva.

Hasil dari proses pembenihan adalah spat mutiara (benih tiram mutiara). Ukuran spat yang dihasilkan oleh semua responden beragam, berkisar antara ukuran $0,3 \mathrm{~mm}-30 \mathrm{~mm}$ yang masih menempel pada substrat (media penempel). Secara kuantitatif, panjang spat yang dihasilkan oleh responden berkisar antara 0,5 $\mathrm{mm}-1,0 \mathrm{~mm}$.

Untuk memastikan spat sesuai dengan kualitas yang ditentukan, maka keberadaan standar sangat diperlukan sebagai upaya untuk meningkatakan jaminan mutu dan keamanan pangan, mengingat selain induk, spat juga memliki pengaruh terhadap proses pembesaran serta mutu mutiara yang nantinya dihasilkan. SNI 8146.2:2015 telah menetapkan persyaratan kualitatif dan kuantitatif serta cara pengukuran dan pemeriksaan spat. Persyaratan kualitatif yang ditetapkan disajikan dalam Tabel berikut: 
Tabel 3 Kriteria kualitatif dan kuantitatif serta cara pengukuran dan pemeriksaan spat.

\begin{tabular}{|c|c|c|}
\hline & SPAT $0,5 \mathrm{~mm}-1,0 \mathrm{~mm}$ & SPAT $10 \mathrm{~mm}-30 \mathrm{~mm}$ \\
\hline Asal & $\begin{array}{l}\text { Larva yang siap menempel pada } \\
\text { substrat. }\end{array}$ & $\begin{array}{l}\text { Spat dari hatchery ukuran } 500 \mu \mathrm{m}-1.000 \mu \mathrm{m} \\
\text { yang me nempel pada substrat. }\end{array}$ \\
\hline Warna & $\begin{array}{l}\text { transparan dan terdapat bitnik hitam } \\
\text { pada bagian cangkang rawannya }\end{array}$ & $\begin{array}{l}\text { Hijau, hijau kehitaman, coklat, coklat kehitaman, } \\
\text { coklat kekuningan }\end{array}$ \\
\hline Bentuk tubuh & $\begin{array}{l}\text { Memiliki sepasang cangkang rawan } \\
\text { berbentuk pipih dan cembung } \\
\text { menyerupai tiram dewasa }\end{array}$ & $\begin{array}{l}\text { Memiliki spasang cangkang rawan yang } \\
\text { berbentuk pipih dan cembung dengan diameter } \\
\text { dari dorsal sampai ventral dan dari anterior } \\
\text { sampai posterior hampir sama sehingga } \\
\text { bentuknya hampir bundar. }\end{array}$ \\
\hline Kesehatan & $\begin{array}{l}\text { Spat menempel kuat pada substrat } \\
\text { yang ditandai dengan tidak rontok } \\
\text { pada saat substrat diangkat dari air } \\
\text { media pemeliharaan }\end{array}$ & $\begin{array}{l}\text { Spat menempel kuat pada substrat yang ditandai } \\
\text { dengan tidak rontok pada saat substrat diangkat } \\
\text { dari air media pemeliharaan }\end{array}$ \\
\hline Gerakan & & $\begin{array}{l}\text { Respon cepat pada saat ada gangguan dari luar, } \\
\text { uaitu dengan menutup rapat cangkangnya }\end{array}$ \\
\hline Mantel & & Memenuhi semua ruang cangkang bagian dalam \\
\hline
\end{tabular}

\subsubsection{Growing (Pendederan)}

Pendederan merupakan kegiatan lanjutan setelah pemeliharaan spat di hatchery yang akan dilakukan di laut. Metode pendederan yang dlakukan oleh seluruh responden penelitian adalah metode longline dan pada satu siklus diperlukan waktu minimal 12 bulan dengan ukuran spat antara 6-8 $\mathrm{cm}$. Metode longline ini digunakan untuk menggantung pocket yang berisikan spat kolektor hingga anti spat berukuran siap panen.

Responden menyampaikan bahwa pemeliharaan dilakukan dengan pembersihan, seleksi menurut ukuran dan penjarangan. Pembersihan dilakukan 1 bulan sekali setelah penebaran, pembersihan ini dilakukan dengan mengangkat spat dari kolektor dan cangkang dibersihkan dengan menggunakan sikat gigi halus, setelah bersih spat ditempatkan pada pocket yang diselubungi waring dan digantung pada longline. Pendederan dilakukan dengan memasukkan induk tiram ke dalam keranjang kawat dan digantung pada rakit dengan kedalaman kurang lebih 7 meter.

SNI 7874:2013 mengatur tentang pendederan spat tiram mutiara dengan metode long line. Responden penelitian menyatakan tidak menggunakan SNI tersebut sebagai referensi dalam melakukan kegiatan pendederan, namun ternyata kegiatan pendederan yang dilakukan sebagian besar telah sesuai dengan persyaratan SNI. Hasil penelitian menunjukkan bahwa pada saat pendederan, hal - hal yang perlu diiperhatikan anatara lain lokasi, kualitas air, konstruksi longline, spat, serta peralatan dan sarana penunjang.
Pada proses pendederan, seleksi dilakukan pada saat penjarangan. Penjarangan bertujuan mengurangi tingkat kepadatan spat persatuan ruang yang dilakukan pada saat pembongkaran spat pada kolektor yang ukurannya mencapai 1 $\mathrm{cm}$. Hasil dari tahap pendederan ini adalah tiram yang siap dilakukan operasi (insersi).

\subsubsection{Insersi Nukleus}

Dalam proses pembentukan mutiara murni, benda asing yang terperangkap dengan sendirinya di tubuh tiram dirubah menjadi mutiara. Untuk tiram mutiara budidaya, campur tangan manusia terjadi pada saat proses memasukkan benda asing ke dalam tubuh manusia. Benda yang dimasukkan dinamakan nukleus mutiara dan lapisan jaringan lunak dari tubuh tiram (saibo). Seluruh responden menyebutkan bahwa tiram mutiara yang siap diinsersi adalah mutiara bulat berumur sekitar 2 tahun dengan masa pemeliharaan. Tiram mutiara yang bisa menghasilkan mutiara dengan mutu yang baik bisa diinsersi lagi dengan memasukkan nukleus yang ukurannya lebih besar dan dipelihara lagi 2 tahun untuk menghasilkan mutiara yang lebih besar pula.

Setelah pemasangan inti selesai dilakukan, segera memasukkan kembali tiram yang telah dioperasi ke dalam pocket keranjang dan digantung di rakit pemeliharaan atau harus segera dimasukkan ke dalam air dengan perlakuan yang sangat hati-hati untuk diistirahatkan.

Pengolahan data hasil wawancara dengan responden menunjukkan hal-hal yang 
perlu dipersiapkan pada saat proses insersi yang dijabarkan dalam Tabel 4 .

Tabel 4 Persyaratan dalam melaksanakan insersi.

\begin{tabular}{|c|c|c|c|c|}
\hline No. & Kriteria & Wajib & Boleh & Dilarang \\
\hline 1. & Seleksi tiram siap insersi & $\sqrt{ }$ & & \\
\hline 2. & Pemuasaan (Yokusei) & $\sqrt{ }$ & & \\
\hline 3. & $\begin{array}{l}\text { Penggunaan alat dan bahan pembantu } \\
\text { Lampu sorot, lampu kepala } \\
\text { Eosin saibo tracer } \\
\text { Kertas alas saibo }\end{array}$ & & $\begin{array}{l}\sqrt{ } \\
\sqrt{ } \\
\sqrt{ }\end{array}$ & \\
\hline 4. & $\begin{array}{l}\text { Nucleus } \\
\text { Grade } \\
\text { Biocote pearl nucleus } \\
\text { Organic baroque } \\
\text { Bironite } \\
\text { cangkang kima yang dilindungi (Giant } \\
\text { Clam / Tridacna sp) }\end{array}$ & $\begin{array}{l}\text { A untuk produksi SSP } \\
\text { Pintada maxima }\end{array}$ & 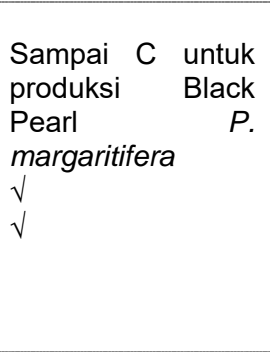 & $\begin{array}{l}\sqrt{ } \\
\sqrt{ }\end{array}$ \\
\hline 5. & $\begin{array}{l}\text { Saibo } \\
\text { Asal }\end{array}$ & $\begin{array}{l}\text { Donor dan resipien } \\
\text { sama spesies }\end{array}$ & & \\
\hline & $\begin{array}{l}\text { Waktu insersi } \\
\text { Teknisi khusus penyedia saibo }\end{array}$ & $<20$ menit & $\begin{array}{l}\text { Menit } \\
\sqrt{ }\end{array}$ & $>30$ menit \\
\hline 6. & $\begin{array}{l}\text { Alat insersi } \\
\text { Steril } \\
\text { Pisau insersi, pisau dan gunting } \\
\text { mantel sangat tajam }\end{array}$ & $\begin{array}{l}\sqrt{ } \\
\sqrt{ }\end{array}$ & & \\
\hline 7. & $\begin{array}{l}\text { Insersi } \\
\text { Insersi pertama (Cultured Pearl/CP) } \\
\text { Pertama memasukkan nucleus baru } \\
\text { dimasukkan saibo } \\
\text { Saibo masuk dulu baru nucleus } \\
\text { Insersi kedua dan seterusnya (Direct } \\
\text { Operation/DO) } \\
\text { Masuk nukleus tanpa saibo } \\
\text { Masuk nukleus dengan saibo }\end{array}$ & $\sqrt{ }$ & $\begin{array}{l}\sqrt{ } \\
\sqrt{ }\end{array}$ & \\
\hline 8. & Waring pembungkus tiram insersi & & $\sqrt{ }$ & \\
\hline 9. & $\begin{array}{l}\text { Penempatan tiram insersi } \\
\text { Keranjang insersi anterior menghadap } \\
\text { ke atas } \\
\text { Pocket net cangkang kiri diatas }\end{array}$ & $\begin{array}{l}\sqrt{ } \\
\sqrt{ }\end{array}$ & & \\
\hline 10. & Tento & & $\sqrt{ }$ & \\
\hline 11. & $\begin{array}{l}\text { Pemeriksaan retensi nukleus } \\
\text { berkandung } \\
\text { Ronsen } \\
\text { Manual }\end{array}$ & $\sqrt{ }$ & $\begin{array}{l}\sqrt{ } \\
\sqrt{ }\end{array}$ & \\
\hline
\end{tabular}

Sumber: hasil penelitian (diolah)

Semua responden menyampaikan proses selanjutnya setelah insersi adalah proses membolak balikkan posisi tiram yang disebut dengan proses tento. Pada saat proses tento ini, petugas juga menjaga kebersihan dari tiram yang dipelihara, termasuk dari gangguan hama, organisme, dan predator. Pemeliharaan berlangsung selama 1-2 tahun dengan proses pengecekan berkala ( 1 bulan sekali).

Responden melakukan upaya dalam meminimalisir penyakit pada tiram mutiara, antara lain:

- Menjaga salinitas air agar dalam kisaran yang dibutuhkan 
- Menjaga suhu air

- Pemilihan lokasi budidaya dengan tingkat kecerahan cukup bagus

- Lokasi tidak pada perairan dasar dan berlumpur

\subsubsection{Harvesting (panen)}

\section{a. Mutiara}

Hasil panen dalam budidaya tiram mutiara ini antara lain: mutiara, cangkang dan daging. Mutiara laut selatan merupakan produk hasil perikanan berupa permata dengan varian warna silver (putih keperakan) sampai warna golden (kuning keemasan) yang dihasilkan oleh Pinctada maxima yang dibudidayakan di perairan laut.

Seluruh responden menyampaikan bahwa dalam pemeliharaan tiram mutiara ini, pengecekan dilakukan secara manual dan scanning dalam kurun waktu tertentu. Untuk tiram yang mampu menghasilakn mutiara bagus, maka tiram tersebut diinsersi kembali untuk kedua kalinya tanpa menyertakan mantel. Biasanya mutiara yang dihasilkan untuk insersi yang kedua, tidak sebagus mutiara hasil insersi pertama.

Tiram jenis Pinctada maxima akan menghasilkan mutiara laut selatan, dimana mutu dari mutiara ini ditetapkan dengan SNI 4989:2016. Standar ini disusun dan ditetapkan berdasarkan persyaratan mutu yang dimiliki oleh perusahaan budidaya tiram mutiara. Sayangnya, seluruh responden yang dijadikan objek dalam penelitian ini, belum mengetahui dan tidak menggunakan SNI 4989:2016 sebagai referensi sortasi mutiara yang dihasilkan.

Parameter yang ditetapkan dalam SNI 4989:2016 dapat dijabarkan dalam Tabel berikut:

Tabel 5 Parameter mutu butiran mutiara laut selatan.

\begin{tabular}{|c|c|c|c|c|}
\hline Bentuk (shape) & $\begin{array}{l}\text { Noda/luka } \\
\text { (spotted) }\end{array}$ & Kemilau (luster) & Warna (color) & Ukuran (size) \\
\hline $\begin{array}{ll}\text { - } & \text { Round (bulat) } \\
\text { - } & \text { Near/semi } \\
& \text { round (agak } \\
& \text { bulat) } \\
\text { - } & \text { Oval } \\
\text { - } & \text { Drop } \\
\text { - } & \text { Fat button } \\
\text { - } & \text { Flat button } \\
\text { - } & \text { Tokki } \\
& \text { (protrude) } \\
& \text { tonjolan } \\
\text { - } & \text { Semi baroque } \\
\text { - } & \text { Baroque } \\
\text { - } & \text { Circle }\end{array}$ & $\begin{array}{ll}\text { - } & \text { Tanpa noda } \\
\text { (non spot) } \\
\text { - } \\
\text { Hampir tidak } \\
\text { ada noda (spot) } \\
\text { - }>10 \%-20 \% \\
\text { noda } \\
\text { - }>30 \% \text { noda }\end{array}$ & $\begin{array}{ll}\text { - } & \begin{array}{l}\text { Sempurna } \\
\text { (excellent) }\end{array} \\
\text { - } & \text { Sangat bagus } \\
& \text { (very good) } \\
\text { - } & \text { Bagus (good) } \\
\text { - } & \text { Sedang (fair) } \\
\text { - } & \text { Kurang (poor) }\end{array}$ & 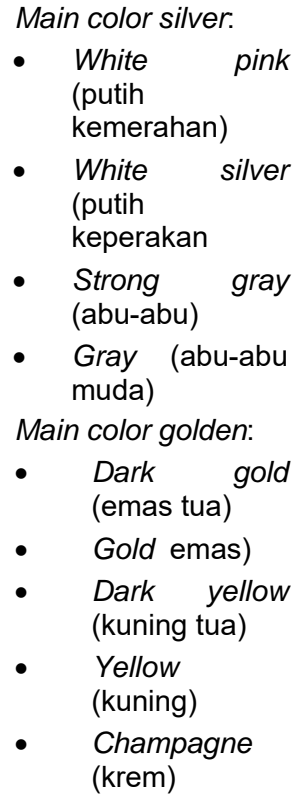 & $8 \mathrm{~mm}-22 \mathrm{~mm}$ \\
\hline
\end{tabular}

Sumber: BSN, 2016.

\section{b. Cangkang dan daging}

Responden menyampaikan bahwa cangkang yang dihasilkan sebagai hasil samping budidaya tiram mutiara digunakan oleh perusahaaan kosmetik dan kriya sebagai bahan baku. Kulit tiram (cangkang) merupakan limbah setelah tiram tidak dapat lagi menghasilkan mutiara yang tebaik. Cangkang tiram digunakan sebagai bahan baku pembuatan cinderamata (gantungan kunci, bros, liontin, plakat, cincin, kalung, dan berbagai jenis mengikuti pesanan dari pelanggan. Pengrajin kosmetik disekitar perusahaan memanfaatkan bubuk cangkang tiram sebagai bahan baku. Daging tiram daging otot aductor yang bisa jadi bahan makanan dan pakan ikan

\subsection{Faktor-faktor pengendali keberhasilan budidaya tiram mutiara}

Pengolahan data hasil penelitian menunjukkan bahwa dalam budidaya tiram, terdapat faktor- 
faktor yang menentukan keberhasilan yang dijabarkan dalam penjelasan berikut.

\subsubsection{Faktor internal (pra insersi)}

\section{a. Seleksi}

Seleksi awal dilakukan pada saat tiram mutiara berumur kurang lebih 18 bulan dengan cara memilih dan memilah berdasarkan ukuran DVM (Dorso Ventral Measurement) diatas $11 \mathrm{~cm}$ dan/atau berat diatas 200 gram. Dalam seleksi ini, pemeriksaan kesehatan dilakukan dengan melihat visual bagian luar tiram serta kondisi gonad. Setelah kurang lebih berusia 24 bulan, tiram yang tidak memiliki ukuran seperti yang sudah ditentukan, maka dianggap afkir (kuntet) dan tidak diinsersi.

\section{b. Yokusei (Conditioning)}

Proses ini dinamakan yokusei yang dilakukan kurang lebih selama 2 bulan. Proses ini bertujuan untuk mengurangi asupan makanan ke dalam tubuh tiram, yang dilakukan dengan beberapa cara, antara lain:

- Memperdalam posisi wadah tiram hasil seleksi lebih dari $5 \mathrm{~m}$

- Menempatkan berjejal pada keranjang tertutup

- Melipat gandakan jumlah tiram pada setiap kantong/pocket net atau sekat keranjang

c. Penyiapan insersi

Persiapan insersi dilakukan dengan pemasangan baji pada tiram yang mau membuka cangkangnya sendiri menggunakan tang pembuka cangkang. Tiram yang tidak mau membuka cangkangnya bisa dimanipulasi dengan pengeringan bak penampung tiram siap insersi. Tiram yang telah dipasang baji wajib dibersihkan dari biofouling yang ada dicangkang bagian luar maupun engsel pembuka bagian dorsal.

\section{d. Penyiapan nukleus}

Nukleus yang akan dimasukkan ke dalam tubuh tiram harus diketahui grade dan jenis nya, karena tidak boleh memasukkan nukleus yang berasal dari cangkang tiram yang dilindungi.

e. Peralatan insersi

Pemastian peralatan insersi yang steril dan tajam penting dilakukan untuk memastikan keselamatan dan keberhasilan proses insersi.

\section{f. Penyiapan saibo}

Tiram donor saibo sudah disiapkan lebih dahulu atau teknisi insersi memilih tiram yang sehat dengan warna dan kemilau cangkang bagian dalam berkualitas tinggi. Pemotongan otot aductor (adductor muscle) harus meggunakan pisau yang sangat tajam dengan sekali iris otot sudah terbelah. Pengguntingan mantel dilakukan 156 dengan cepat dan dengan menggunakan gunting yang sangat tajam sehingga waktu pemotongan terdengar seperti suara desainer baju yang sedang memotong kain. Pembuatan saibo dilakukan dengan scalpel (pisau bedah) dengan cepat dan ukuran yang sama

\subsubsection{Internal (pasca insersi)}

Setelah proses penyuntikan dilakukan, pemeliharaan pasca insersi dilakukan dengan cara sebagai berikut:

\section{a. Penempatan dalam wadah}

Penempatan pada wadah keranjang dilakukan dengan posisi anterior berada diatas agar lebih sulit keluar nukleus. Penempatan pada poket net dilakukan dengan posisi cangkang kiri tiram berada diatas pada posisi poket net miring. Sebaiknya dilakukan dengan ditumpuk dua poket tetapi diberi jarak antar poket sekitar $10 \mathrm{~cm}$ agar posisi dalam air lebih stabil. Bila akan dilakukan tento maka harus menggunakan wadah keranjang dengan sekat penuh (keranjang tento)

b. Tento

Tento dilakukan setelah masa pemeliharaan sekitar 2 minggu - 4 minggu pasca insersi dengan cara membolak balik keranjang setiap tiga hari sekali selama 45 hari. Tujuan tento adalah supaya pelapisan mutiara seimbang sehingga hasil mutiaranya banyak yang bulat (round/near round)

\section{c. Pemeriksaan retensi}

Pemeriksaan retensi dilakukan setelah insersi sekitar 3 bulan dilakukan pemeriksaan nukleus masih pada posisi(berkandung) atau sudah dikeluarkan (muntah). Pemeriksaan bisa dilakukan dengan bantuan ronsen. Pemeriksaan manual dilakukan dengan bantuan spatula berujung bulat agar tidak melukai organ tubuh tiram. Pemeriksaan menggunakan ronsen sebaiknya dilakukan sesuai SOP agar kesehatan petugas ronsen tetap terjaga

\subsubsection{Eksternal}

Selain faktor internal yang berpengaruh dalam keberhasilan budidaya tiram mutiara, faktor eksternal juga menjadi sangat penting.

a. Pencemaran

Pada industri budidaya tiram mutiara sering terjadi kematian massal yang disebabkan oleh adanya pencemaran. Budidaya tiram mutiara yang berlokasi di wilayah tercemar menyebabkan tiram megalami tekanan (stress) (Sutaman, 1993).

Selain bahan pencemar yang mengganggu budidaya tiram mutiara, keberadaan bakteri, parasit, predator, organisme 
penempel, virus juga dilaporkan dapat mempengaruhi keberlangsungan budidaya tiram mutiara (Anggorowati, 2008).

\section{b. Climate change}

Perubahan iklim yang menyebabkan perubahan suhu dan salinitas secara fluktuatif juga dilaporkan menyebabkan kematian tiram mutiara (Pinctada maxima) pada musim dingin. (Anggorowati, 2008).

\section{KESIMPULAN}

Proses operasi (insersi) merupakan proses penting yang melibatkan campur tangan manusia dalam budidaya tiram mutiara. Dalam proses insersi ini, membutuhkan bibit nukleus (inti mutiara) serta donor tiram (saibo) untuk diambil mantel tissue (organ lunak mutiara). Persyaratan dalam pelaksanaan insersi tiram mutiara adalah seleksi tiram mutiara, yokusei, penyiapan saibo, penyiapan nukleus, alat insersi, penempatan dalam wadah, tento, pemeriksaan retensi. Keahlian, ketelitian dan kesabaran insertor juga menjadi faktor penentu keberhasilan budidaya tiram mutiara. Pengembangan SNI untuk teknik insersi tiram mutiara tidak perlu dilakukan karena faktor eksternal (lingkungan) lebih mendominasi terhadap pembentukan mutiara dalam tubuh tiram. Hal ini didukung dengan belum adanya penelitian yang menunjukkan hasil mutiara dengan kualitas yang seragam dengan teknik insersi yang sama. Penyusunan tata cara dan persyaratan proses insersi tiram mutiara dijadikan pedoman pendukung standardisasi kegiatan budidaya tiram mutiara.

\section{UCAPAN TERIMA KASIH}

Penulis mengucapkan terimakasih kepada pimpinan Badan Standardisasi Nasional (BSN) yang telah mengalokasikan anggaran untuk penelitian ini. Ucapan terimakasih juga disampaikan kepada Gustaf Mamangkey, S.Pi, M.Sc., Ph.D (Universitas Sam Ratulangi), Ir. Mulyanto, M.Ed (Sekolah Tinggi Perikanan), dan pembudidaya tiram mutiara di wilayah Bali, Labuan Bajo dan Manado, serta tim Puslitbang BSN yang telah memberikan pemikiran dan berpartisipasi dalam penelitian ini.

\section{DAFTAR PUSTAKA}

Anggorowati, D, A. (2008). Kematian masal pada usaha budidaya Kerang mutiara. Oseana, Vol. XXXIII, No. 2, Tahun 2008 : $9-14$.
BI. (2004). Pola Pembiayaan Usaha Kecil (PPUK) Budidaya Mutiara. Jakarta.

BSN. (2013). SNI 7874:2013 Pendederan spat tiram mutiara, Jakarta.

(2015). SNI 8146.1:2015 Tiram mutiara induk, Jakarta.

(2015). SNI 8146.2 - 2015 Tiram mutiara spat, Jakarta.

(2016). SNI 4989 - 2016 Mutiara laut selatan, Jakarta.

Fathurrahman \& Aunurohim. (2014). Kajian komposisi fitoplankton dan hubungannya dengan lokasi budidaya Kerang mutiara (P. Maxima) di perarian Sekoteng, Nusa Tenggara Barat. Jurnal Teknik Pomits Vol. 3, No. 2, (2014) : 93 - 98. ISSN: 2337-3539.

Gervis \& Sims, (1992). The Biology and culture of Pearl Oysters (Bivalvia: Pteriidae). ICLARM Studies and review 21. The Overseas Development. Philippines.

Hakim. A. R. (2015). Proses Terjadinya Mutiara Laut. http://originalmutiara.com. Diakses tanggal 18 Oktober 2017.

Hamzah, M.S. (2009). Studi pertumbuhan dan kelangsungan hidup anakan kerang mutiara (Pinctada maxima) dengan menggunakan keranjang tento pada kedalaman yang berbeda di teluk Kodek, Lombok Barat. Prosiding Pertemuan IImiah Tahunan ISOI 2008, Bandung : 232-239.

Hamzah, M.S. (2013). Daya penempelan kerang mutiaran (pinctada maxima) pada kolektor dengan posisi tebal dan kedalaman berbeda. Jurnal IImu dan Teknologi Kelautan Tropis, Vol. 5, No. 1 : 60-68, Juni 2013.

Kementerian Kelautan dan Perikanan (KKP). (2016). Laporan Kinerja Kementerian Kelautan dan Perikanan. Jakarta.

Kotta, R. (2018). Teknik pembenihan tiram mutiara (Pinctada maxima). Prosiding Seminar Nasional KSP2K II, 1 (2) : 228 244.

Makhas, K, A., Mamangkey, G, F., Mantiri, D, M, H. (2014). Perkembangan mutiara mabé pada pinctada margaritifera di perairan Arakan, Sulawesi utara. Jurnal Pesisir dan Laut Tropis Volume 1 Nomor 1 Tahun 2014: 13 - 18.

Puslitbang BSN. (2017). Laporan Penelitian Pengembangan Standar Budidaya Tiram Mutiara: Teknik Insersi. Jakarta. 
Mulyanto. (2017). Dukungan Penelitian dan Pengembangan SNI Teknik Insersi Mutiara. Makalah disampaikan di BSN tanggal 6 April 2017.

Sudewi., Supii, A, I., dan Rusdi, I. (2010). Pendederan tiram mutiara (pinctada maxima) dengan perbedaan ukuran tebar awal. Prosiding forum inovasi teknologi akuakultur. HIm: 325-330.

Sudewi., Supii, A.I., Sutarmat, T., Yudha, H, T. (2010). Pendederan tiram mutiara, pinctada maxima dengan perbedaan kedalaman. Jurnal Perikanan (J. Fish. Sci.) XII (2): 57-63. ISSN: 0853-6384.

Sukadi, M.F. (2002). Peningkatan Teknologi Budidaya Perikanan. Jurnal Iktiologi Indonesia. Vol. 2, No. 2 Tahun 2002: 6164.

Sumarto., Hariyadi. P., Purnomo, E, H. (2014). Kajian Proses Perumusan Standar dan Peraturan Keamanan Pangan di Indonesia. Jurnal Pangan. Vol 23, No 2 (2014).

Sutaman. (1993). Tiram Mutiara, Teknik Budidaya dan Proses Pembuatan Mutiara. Penerbit Kanisius. Yogyakarta.
Trademap. (2017). Trade Statistic for International Bussiness Development. HS7101.www.trademap.org. Diakses terakhir tanggal 18 Oktober 2017.

Taufiq, N., Hartati, R., Cullen, J., Masjhoer, J, M. (2007). Pertumbuhan Tiram Mutiara (pixctada maxima) pada kepadatan berbeda. Ilmu Kelautan. Maret 2007. Vol. 12 (1): $31-38$.

Taufiq, N., Rachmawati, D., Cullen, J., dan Yuwono. (2010). Aplikasi Isochrysis galbana dan Chaetoceros amami serta kombinasinya terhadap pertumbuhan dan kelulushidupan veliger-spat tiram mutiara (Pinctada maxima). IImu Kelautan, 15(3): 119-125.

Winanto, T., Pontjoprawiro, S., Murdjani, M. (1992). Budidaya Mutiara. Balai Budidaya Laut Lampung \& FAO/UNDP. INS/81/008.

Winanto T. (2009). Kajian perkembangan larva dan pertumbuhan spat tiram mutiara Pinctada maxima (Jameson) pada kondisi lingkungan pemeliharaan berbeda. Thesis. Sekolah Pascasarjana IPB. Bogor. 